\title{
LA POSIBILIDAD DE CONVALIDACIÓN EN EL ÁMBITO CONTRACTUAL CIVIL
}

\author{
M. ${ }^{a}$ Isabel CADENAS GARCÍA \\ Abogada del Estado \\ Ministerio de Educación, Cultura y Deporte \\ isabel.cadenas@mecd.es
}

\begin{abstract}
RESUMEN
La doctrina y la jurisprudencia del Tribunal Supremo coinciden en calificar como negocios jurídicos incompletos aquellos negocios jurídicos que se realizan $\mathrm{sin}$ la previa autorización judicial o administrativa. También coinciden en considerar que tales negocios jurídicos incompletos son susceptibles de convalidación por la posterior autorización judicial o administrativa, incluso así lo contempla el RF en determinados supuestos en que falta la previa autorización del Protectorado cuando se han realizado actos de disposición o gravamen sin la misma.
\end{abstract}

Palabras clave: negocios incompletos, autorización judicial o administrativa, nulidad, anulabilidad, convalidación.

\section{ABSTRACT}

The Supreme Court's Doctrine and Case Law agree to classify as unfinished law business the business which takes place without a prior legal or administrative authorization. They also agree on considering such unfinished business as open to being validated by its ultimate legal or administrative authorizing, it is also seen by the Foundation Rules for those particular cases without the authorizing from the Protectorate when an activity of disposal or a tax-based activity has occurred without being authorized.

Keywords: Unfinished business, legal/administrative authorization, nullity, annulability, validating.

\section{ZUSAMMENFASSUNG}

Die Lebre und Rechtsprechung des Obersten Gerichtshofs stimmt darin überein, dass diejenigen Rechtsgeschäfte unvollständig sind, die obne vorherige rechtliche oder verwaltungsrechtliche Erlaubnis zustandegekommen sind. Ebenso stimmen sie darin überein, dass solche unvollständigen Rechtsgeschäfte der nachträglichen Bestätigung durch ein Gericht oder Verwaltungsgericht bedürfen, sogar, und so siebt es das durch ein Gericht oder Verwaltungsgericht bedürfen, sogar, und so siebt es das spanische Wirtschafts- und Steuersystem REF in bestimmten Fällen vor, wenn die Genehmigung der Aufsichtsbehörde fehlt und Verfügungen und finanzielle Erbebungen vorgenommen wurden.

Schlüsselwörter: Unvollständige Rechtsgeschäfte, juristische oder verwaltungsrechtliche Erlaubnis, Nichtigkeit, Anfechtbarkeit, rechtliche Bestätigung. 
SUMARIO: I. INTRODUCCIÓN.-II. DOCTRINA GENERAL SOBRE LA NULIDAD.-1. Supuestos concretos de nulidad.-2. Aplicación de los supuestos concretos de nulidad en diversos ámbitos.-3. Convalidación de actos nulos.-III. DOCTRINA GENERAL SOBRE LA ANULABILIDAD.-1. Supuestos concretos de anulabilidad.-2. Confirmación de actos anulables.-IV. CASOS CONCRETOS DE NEGOCIOS JURÍDICOS INCOMPLETOS POR FALTA DE LA AUTORIZACIÓN PREVIA PREVISTA EN LAS DISPOSICIONES LEGALES: CONSECUENCIAS Y POSIBILIDAD O NO DE CONVALIDARLOS.-1. En el ámbito del Derecho civil.-A. Los negocios jurídicos realizados por los representantes legales de los hijos menores de edad sin la pertinente autorización judicial que es exigible conforme a lo dispuesto en el art. 166 del Código Civil.-B. Los negocios jurídicos realizados por el tutor sin la necesaria autorización judicial.-C. Los actos de disposición relativos a bienes gananciales efectuados por el esposo tutor sin autorización judicial.-2. En el ámbito del Derecho administrativo.-A. Falta de autorización previa en el supuesto de subcontratación de actividades subvencionadas en materia de subvenciones públicas.-B. Falta de autorización previa del Protectorado en el caso de autocontratación en materia de fundaciones.-C. Falta de autorización previa del Protectorado en caso de enajenación o gravamen de los bienes y derechos que forman parte de la dotación o están directamente vinculados al cumplimiento de los fines fundacionales, en materia de fundaciones.-V. CONCLUSIONES.

\section{INTRODUCCIÓN}

Fuera de la tradicional diferenciación entre lo que sucede en el ámbito civil, en el que la nulidad es la regla y la anulabilidad la excepción, y en el ámbito administrativo, en el que sucede lo inverso, en el segundo existe la figura de la convalidación de los actos administrativos anulables prevista en el art. 52.4 $\mathrm{LPAC}^{1}$, que permite, de no concurrir causa de nulidad de pleno derecho y subsanando los vicios de que adolezcan, la sanación de los mismos (art. 52.4 LPAC: «si el vicio consistiese en la falta de alguna autorización, podrá ser convalidado el acto mediante el otorgamiento de la misma por el órgano competente»).

Esta medida, de fácil encuadre en el mundo administrativo, no resulta de tan fácil solución en el campo del Derecho civil. En efecto, en el Derecho civil la «regla general» es que la vulneración de una norma (imperativa) deba ser sancionada con la nulidad, mientras que la anulabilidad se reserva para los supuestos específicamente contemplados en el ordena-

${ }^{1}$ La Ley 39/2015, de 1 de octubre, de Procedimiento Administrativo Común de las Administraciones Públicas ( $B O E$ de 2 de octubre), que entró en vigor al año de su publicación en el $B O E$, salvo determinadas previsiones relativas al registro electrónico de apoderamientos, registro electrónico, registro de empleados públicos habilitados, punto de acceso general electrónico de la Administración y archivo único electrónico, que producirán efectos a los dos años de la entrada en vigor de la Ley (disposición final séptima). 
miento, sin perjuicio del principio de conservación de los actos y negocios jurídicos (favor contractii).

Ya de antiguo Federico de Castro y Bravo ${ }^{2}$ realizó una primera aproximación a lo que podríamos denominar como «convalidación civil», que consideró para aquellos casos de subsanación de los negocios incompletos, en particular la de aquellos en que el negocio requiere para su validez una autorización posterior que venga a subsanar la nulidad.

En este sentido, Pascual Marín Pérez ${ }^{3}$, con anterioridad a él, había afirmado que «la disposición del art. 4 del Código Civil (en la redacción anterior a la reforma de 1973, que es el antecedente del actual art. 6) ha de entenderse, pues, en el sentido de que la ley ordene por sí la validez del acto, que sería nulo en otro caso, o en el que permita la convalidación por las personas interesadas o por decisión de los Tribunales». Así lo estableció ya el Tribunal Supremo en Sentencia de 8 de febrero de 1886, declarativa de que «cualquiera que fuese el vicio de que pudiera adolecer un acto o contrato, quedó convalidado por el reconocimiento que de él hizo la otra parte, ratificándolo por actos posteriores que demostraban la voluntad de tenerlo por válido y eficaz». Por ejemplo, y en materia de fundaciones, en su vertiente civil, la posibilidad de subsanar actuaciones de la fundación cuando la autorización necesaria del Protectorado, no reclamada inicialmente y antes de formalizarse el negocio jurídico, se obtiene, sin embargo, con posterioridad, supuesto que es el que planteó las dudas que el presente artículo trata.

Por otra parte, la nulidad y la anulabilidad de los negocios jurídicos son categorías que se comprenden, entre otras, dentro del concepto general de ineficacia, respecto del que la doctrina ha efectuado algunas consideraciones.

Por lo que se refiere al concepto general de ineficacia, Luis Díez Pica$\mathrm{zo}^{4}$ sostiene que «la idea de ineficacia del contrato representa la contrapar-

${ }^{2}$ F. de Castro y Bravo, El negocio jurídico, Madrid, Civitas, 1985, pp. 485 y 486, e íD., Derecho Civil de España. Parte General, t. I, Libro Preliminar. Introducción al Derecho Civil, 3. a ed., Madrid, Instituto de Estudios Políticos, 1955, pp. 559 y 660.

En este último libro el citado autor entiende que los actos incompletos, a diferencia de lo que ocurre con los actos ilícitos, pueden ser completados, revalidados o confirmados. Es cierto que en dicho libro entiende que tales actos incompletos no pueden considerarse nulos, a diferencia de lo que sostiene posteriormente sobre la convalidación de los actos o negocios nulos como son los negocios incompletos.

3 P. Marín Pérez, Quintus Mucius Scaevola. Código Civil. Comentado y concordado extensamente y totalmente revisado y puesto al día, t. I, 6. ${ }^{a}$ ed., Madrid, Instituto Editorial Reus, 1949, pp. 250 у 251.

${ }^{4}$ L. Dí́zz Picazo, Fundamentos del Derecho Civil Patrimonial, t. I, Introducción: teoría del contrato, Madrid, Civitas, 1996, p. 423. 
tida a la idea de eficacia. Al igual que al hablar de la eficacia se alude a la producción de determinadas consecuencias, a la creación de un deber de observancia del contrato y de una vinculación a lo establecido, así como a la proyección del contrato respecto de o sobre una situación jurídica anterior, cuando se habla de la ineficacia se alude a la falta de producción de consecuencias o, cuando menos, de aquellas consecuencias que normalmente deberían haberse producido y que pueden ser razonablemente esperadas en virtud de la celebración del contrato».

En el campo del Derecho, sigue diciendo Luis Díez Picazo ${ }^{5}$, acontece algo que, «si se mira bien, es enormemente curioso: la ineficacia produce a veces unas consecuencias o unos efectos. Bajo el calificativo de ineficaz se designan toda una serie de supuestos que en cierta medida son heterogéneos. Así, si se dice que un contrato es nulo, se puede aludir a un contrato del que no se deriva en la realidad efecto alguno, porque es considerado por todos irrelevante en el terreno jurídico, o bien a un contrato que produce unos efectos en la realidad, pero que proporciona a los interesados la posibilidad o incluso impone en su caso a los funcionarios, por su propia iniciativa, la obligación o el deber de hacer volver las cosas al ser y estado que tenían antes de ser celebrado dicho contrato, porque éste merece la reprobación y la condena. En otros casos, se llama ineficaz a lo que es sólo limitadamente eficaz o poco eficaz, porque se dan algunos de los efectos esperados y se produce parcialmente el resultado previsto, aunque no todas las consecuencias que eran contempladas ni todos los resultados que se buscaban. Otras veces, con el calificativo de ineficaz se designa algo que es anormalmente eficaz, porque no se producen los efectos que se esperaban, sino unos resultados imprevistos. La única nota rigurosamente común a todos los supuestos que se han tratado de englobar es la existencia de una cierta discrepancia o de una desarmonía entre la eficacia prevista o esperada y la eficacia realmente desarrolla$\mathrm{da}$, es decir, entre el cuadro general de los efectos del contrato y la realidad de esa eficacia. Acaso fuera más exacto hablar de eficacia anormal. La palabra ineficaz tiene, no obstante, una gran fuerza expresiva y parece de fácil manejo, por lo cual, con las aclaraciones ya hechas, merece ser conservada».

5 Ibid., p. 425. 


\section{DOCTRINA GENERAL SOBRE LA NULIDAD}

La doctrina ${ }^{6}$ destaca la imprecisión de conceptos y términos que emplea el Código Civil en toda la materia referida a la ineficacia del contrato. No hay exacta correspondencia entre las palabras y conceptos que maneja la doctrina y la jurisprudencia y las que se utilizan por el legislador civil; por ello se impone la ineludible tarea de adaptación de los términos legales a los doctrinales y viceversa.

El capítulo VI del título II del libro IV del Código Civil, que comprende los arts. 1.300 a 1.314, lleva por epígrafe «De la nulidad de los contratos» y en él la palabra nulidad es utilizada en varios sentidos: unas veces con el mismo alcance que el que le atribuye la doctrina dominante y en otras ocasiones se emplea como equivalente a la anulabilidad; la consecuencia de esta diversidad de conceptos es que siempre que se encuentre utilizada en el Código Civil la palabra nulidad debe realizarse un esfuerzo de interpretación para decidir en cuál de los posibles significados la aplica el legislador.

\section{Supuestos concretos de nulidad}

a) A la nulidad con carácter general, es decir, no sólo referida a los contratos, se refiere el art. 6.3 CC cuando establece que: «Los actos contrarios a las normas imperativas y a las prohibitivas son nulos de pleno derecho, salvo que en ellas se establezca un efecto distinto para el caso de contravención». Si se aplica esta regla general a la ineficacia de los contratos, la consecuencia es que la nulidad es la sanción que el ordenamiento jurídico impone al contrato celebrado contra las previsiones de una norma imperativa o prohibitiva.

b) Los contratos con objeto o causa ilícita ${ }^{7}$ y los contratos celebrados vulnerando los límites del principio de autonomía de la voluntad recogida en el art. 1.255 CC, por ejemplo, por ser contrarios al orden público o a las buenas costumbres, también se consideran por la doctrina contratos nulos.

c) La falta de forma cuando la forma exigida por la ley es un requisito ad solemnitatem también se entiende por la doctrina como una causa de nulidad.

\footnotetext{
${ }^{6}$ E. Serrano Alonso y E. Serrano Gómez, Manual de Derecho de Obligaciones y Contratos, t. II, vol. 1, Teoría General del Contrato, Madrid, Edisofer, 2008, pp. 127 y ss.

7 SAP Castellón de 1 de junio de 2004 (AC 2004/1150).
} 


\section{Aplicación de los supuestos concretos de nulidad en diversos ámbitos}

En particular, se establece la consecuencia de la nulidad por ser el contrato contrario a las normas imperativas y a las prohibitivas en diversas disposiciones en distintos ámbitos:

a) El art. 24.1 de la Ley 20/2015, de 14 de julio, de Ordenación, Supervisión y Solvencia de las Entidades Aseguradoras y Reaseguradoras, prevé que:

«1. Serán nulos de pleno derecho los contratos de seguro celebrados y demás operaciones sometidas a esta Ley realizados por entidad no autorizada, cuya autorización haya sido revocada o que transgredan los límites de la autorización administrativa concedida».

b) La Ley 4/2012, de 6 de julio, sobre contratos de aprovechamiento por turno de bienes de uso turístico, de adquisición de productos vacacionales de larga duración, de reventa y de intercambio y normas tributarias, recoge en el art. 13 una prohibición:

«1. En los contratos de aprovechamiento por turno de bienes de uso turístico, de producto vacacional de larga duración y de intercambio se prohíbe el pago de anticipos, la constitución de garantías, la reserva de dinero en cuentas, el reconocimiento expreso de deuda o cualquier contraprestación a favor del empresario o de un tercero y a cargo del consumidor antes de que concluya el plazo de desistimiento.

2. Las mismas prohibiciones se establecen respecto a los contratos de reventa antes de que la venta haya tenido efectivamente lugar o se haya dado por terminado el contrato por otras vías.

3. Los actos realizados en contra de esta prohibición son nulos de pleno derecho y el consumidor podrá reclamar el duplo de las cantidades entregadas o garantizadas por tales conceptos».

La Sentencia de la Audiencia Provincial de Madrid de fecha 4 de mayo de 2015 (AC 2015/840) declara en relación con esta prohibición que:

«De hecho, cualquier duda sobre la voluntad del legislador en relación al precepto queda despejada con la nueva regulación en la materia, al expresar el art. 13.3 de la Ley 4/2012 (RCL 2012, 946) que "los actos realizados en contra de esta prohibición son nulos de pleno derecho y 
el consumidor podrá reclamar el duplo de las cantidades entregadas o garantizas por tales conceptos", y aunque esta última norma no es aplicable, sirve de apoyo interpretativo de la legislación anterior a que se sujeta el contrato litigioso.

En efecto, siendo el art. 11 LATBI una norma prohibitiva, el acto de cobro de anticipo que proscribe resulta "nulo de pleno derecho" y, por ello, absoluta y totalmente ineficaz, sin posibilidad de sanación ni de confirmación».

c) La disposición adicional octava del Real Decreto-ley 3/2012, de 10 de febrero, referida a las especialidades en los contratos mercantiles y de alta dirección del sector público estatal, dispone que:

«2. Serán nulas de pleno derecho las cláusulas de los contratos mercantiles o de alta dirección a que se refiere la presente disposición que se opongan a lo establecido en la misma».

La Sentencia del Tribunal Superior de Justicia de Madrid de fecha 25 de abril de 2014 (AS 2014/1605) declara que:

«Comenzando por la primera cuestión, hay que aclarar que el RD-ley 3/2012 circunscribe su ámbito de aplicación a la alta dirección en el sector público estatal, es decir, a la Administración General del Estado, organismos autónomos, entidades públicas empresariales, sociedades mercantiles estatales y fundaciones del sector público estatal, como se establece en el apartado primero de la DA 8. ${ }^{a}$ por remisión al art. 2.1 de la Ley 47/2003, General Presupuestaria, quedando excluidos únicamente las entidades gestoras, servicios comunes y las mutuas de accidentes de trabajo y enfermedades profesionales de la Seguridad Social, así como sus centros y entidades mancomunados a las que se refiere la letra $d$ ) del mismo artículo.

En segundo lugar, por lo que se refiere a su contenido, sus principales innovaciones vienen a ser el establecimiento de una estructura retributiva uniforme, la reducción —y supresión, en su caso— de las indemnizaciones por desistimiento de la Administración, y reducción del periodo de preaviso, sin perjuicio de que las limitaciones en materia indemnizatoria puedan ser modificadas por el gobierno en función de la situación económica.

Se fortalece, además, la observancia de tales medidas sancionándose con la nulidad las cláusulas contractuales contrarias a los límites establecidos y advirtiéndose a los órganos competentes la posible derivación de responsabilidades civiles, administrativas, contables y de otra índole caso de incumplir las previsiones normativas referidas, y se impone, asimismo, como 
control preventivo, la obligación de recabar, con carácter previo a la formalización de estos contratos, informe de la Abogacía del Estado u órgano que preste el asesoramiento jurídico del organismo que ejerza el control o supervisión financiera de la entidad del sector público, o, en su caso, del accionista, que pretenda contratar al máximo responsable o directivo».

\section{d) El art. 1.2 de la Ley 15/2007, de Defensa de la Competencia, esta- blece que:}

«2. Son nulos de pleno derecho los acuerdos, decisiones y recomendaciones que, estando prohibidos en virtud de lo dispuesto en el apartado 1 , no estén amparados por las exenciones previstas en la presente Ley».

La Sentencia de la Audiencia Provincial de A Coruña de fecha 10 de noviembre de 2010 (JUR 2011/47106), en relación con la anterior Ley de Defensa de la Competencia, que contenía la misma consecuencia, indica que:

«Para enjuiciar la validez de esta cláusula hemos de acudir al art. 1 de la Ley 16/1989, de 17 de julio, de Defensa de la Competencia —norma en vigor en el momento del contrato-. Es clara la aplicación de dicho artículo cuando exista acuerdo, decisión o recomendación colectiva, práctica concertada que tenga por objeto o produzca el efecto de impedir, restringir o falsear la competencia en todo o en parte del mercado nacional, concretando el apartado segundo del mismo precepto la nulidad de pleno derecho de los acuerdos que, estando prohibidos en el apartado primero, no estén amparados por la presente Ley. Se trata de una declaración de nulidad de lo que infringe la legislación sobre la materia, porque dicha conducta tiende a falsear la competencia, con lo cual deviene ilícita la causa del contrato y la consiguiente nulidad radical en aplicación del art. 1.306 del Código Civil, máxime cuando el acuerdo no es sometido a la autorización del Tribunal de Defensa de la Competencia. Es una cuestión que afecta al orden público, por las repercusiones en el precio y en la calidad, y no es óbice que quien interese la nulidad haya venido cumpliendo voluntariamente el contrato hasta agosto de 2006, porque el art. 1.306 CC contempla los efectos de la nulidad para las partes contratantes, y, por otra parte, también se puede aplicar de oficio la nulidad radical y absoluta derivada de la causa ilícita del contrato en aplicación del art. 1.275 CC. El contrato será nulo de pleno derecho, total o parcialmente, por ser contrario a lo dispuesto en el art. 1 LDC, que además proclama en su Exposición de Motivos que "la competencia, como principio rector de toda economía de mercado, repre- 
senta un elemento consustancial al modelo de organización económica de nuestra sociedad y constituye, en el plano de las libertades individuales, la primera y más importante forma en que se manifiesta el ejercicio de la libertad de empresa. Tal defensa, por ende, de acuerdo con las exigencias de la economía general y, en su caso, de la planificación, ha de concebirse como un mandato a los poderes públicos que entronca directamente con el art. 38 de la Constitución”.

También es cierto que, por derivar la nulidad postulada de una norma de carácter imperativo (art. 1.2 de la Ley 16/1989, de 17 de julio, de Defensa de la Competencia, en relación con el art. 6.3 del Código Civil), los tribunales tienen competencia para el conocimiento de aquella cuestión, siendo necesario analizar la obligatoriedad, cumplimiento o incumplimiento de determinadas cláusulas contractuales cuando el contrato del que fluyen pudiera infringir normas de carácter prohibitivo, como son las que hacen referencia a las practicas impeditivas, restrictivas o de falseamiento de la competencia, siendo la norma nítida a estos efectos; la nulidad que se dispone lo es de pleno derecho, apreciable de oficio por los tribunales. Esta nulidad, que puede ser invocada por cualquier persona, se impone al juez cuando concurren los requisitos de aplicación del art. 85.1 del Tratado Constitutivo de la Comunidad Económica Europea (antes Comunidad Económica Europea) hecho en Roma el 2 de marzo de 1957, derecho comunitario originario según numeración de artículos y redacción anterior al Tratado de Ámsterdam de 1997, y el acuerdo de que se trate no pueda justificar la concesión de una exención en virtud del art. 85, apartado 3, del Tratado. Como la nulidad que establece el art. 85, apartado 2, tiene carácter absoluto, un acuerdo nulo con arreglo a dicha disposición no produce efectos en las relaciones entre las partes contratantes ni es oponible a terceros. Además, esta nulidad puede afectar a todos los efectos, pasados o futuros, del acuerdo o de la decisión de que se trate. En tercer lugar, debe recordarse que el Tribunal de Justicia ya ha declarado que los arts. 85, apartado 1, del Tratado y 86 del Tratado CE (actualmente art. $82 \mathrm{CE}$ ) pueden producir efectos directos en las relaciones entre particulares y que dichos artículos crean derecho a favor de los justiciables que los órganos jurisdiccionales nacionales deben tutelar. Pero también nuestra legislación nacional impone la declaración de nulidad de pleno derecho cuando se infringen disposiciones de carácter imperativo o prohibitivo, como el transcrito art. 6.3 del Código Civil y también el art. 1.2 LDC. También el art. 1.275 del Código Civil considera que la causa de un contrato es ilícita cuando se opone a la ley, y en este caso el contrato no puede producir ningún efecto (en el mismo sentido la jurisprudencia del Tribunal Supremo — ad exemplum, Sentencia de 2 de junio de 2000 - , así como la jurisprudencia menor de las Audiencias Provinciales _ SSAP de Barcelona de 8 de mayo de 2000 y 18 de septiembre de 
2003, SAP de Valencia de 2 de junio de 2003, SAP de Madrid de 15 de septiembre de 2003 y SAP de Girona de 10 de junio de 2004, entre otras-)».

e) El art. 68.1 del Real Decreto Legislativo 1/2007, de 16 de noviembre, por el que se aprueba el Texto Refundido de la Ley General para la Defensa de los Consumidores y Usuarios y otras leyes complementarias, indica que:

«1. El derecho de desistimiento de un contrato es la facultad del consumidor y usuario de dejar sin efecto el contrato celebrado, notificándoselo así a la otra parte contratante en el plazo establecido para el ejercicio de ese derecho, sin necesidad de justificar su decisión y sin penalización de ninguna clase.

Serán nulas de pleno derecho las cláusulas que impongan al consumidor y usuario una penalización por el ejercicio de su derecho de desistimiento».

La Sentencia de la Audiencia Provincial de León de fecha 5 de diciembre de 2015 (AC 2015/117) expone que:

«No existe vulneración de la doctrina jurisprudencial en la decisión que es recurrida. Al contrario, la reciente Sentencia del TS de fecha 11 de marzo de 2014 (RJ 2014, 2114) recoge el siguiente criterio en un contrato de servicios con prestación de mantenimiento de aparatos elevadores celebrado bajo condiciones generales de la contratación: "Se fija como doctrina jurisprudencial que la declaración de abusividad de las cláusulas predispuestas bajo condiciones generales, que expresamente prevean una pena convencional para el caso del desistimiento unilateral de las partes, no permite la facultad judicial de moderación equitativa de la pena convencionalmente predispuesta, sin perjuicio del posible contenido indemnizatorio que, según los casos, pueda derivarse de la resolución contractual efectuada”.

En la demanda se reclama la indemnización derivada de la cláusula del contrato que ha sido declarada nula y no derivada de los perjuicios que efectivamente ha ocasionado la resolución contractual que ha tenido lugar después de vencido el plazo inicial pactado de diez años y ya prorrogado, por lo que la aplicación de la más moderna doctrina jurisprudencial, como por ejemplo la Sentencia de marzo de 2014 citada en el párrafo anterior, impone confirmar la sentencia de primera instancia en su totalidad».

En el mismo sentido, el art. 102 del mismo Real Decreto Legislativo $1 / 2007$, de 16 de noviembre, contempla el desistimiento en los siguientes términos: 
«1. Salvo las excepciones previstas en el art. 103, el consumidor y usuario tendrá derecho a desistir del contrato durante un periodo de catorce días naturales sin indicar el motivo y sin incurrir en ningún coste distinto de los previstos en los arts. 107.2 y 108.

2. Serán nulas de pleno derecho las cláusulas que impongan al consumidor y usuario una penalización por el ejercicio de su derecho de desistimiento o la renuncia al mismo».

f) El art. 12.1 de la Ley 49/2003, de 26 de noviembre, de Arrendamientos Rústicos, dispone que:

«1. Los arrendamientos tendrán una duración mínima de cinco años. Será nula y se tendrá por no puesta toda cláusula del contrato por la que las partes estipulen una duración menor».

La Sentencia de la Audiencia Provincial de Córdoba de fecha 19 de julio de 2007 (AC 2007/2240) explica que:

«Dicho esto, hay que examinar ahora el eje o núcleo fundamental de este litigio y es el relativo a la duración del contrato, que si nos atenemos a la literalidad del documento aportado es "la campaña de recolección de aceitunas 04/05". Con ello parece que se está haciendo alusión a un contrato de arrendamiento de temporada al que se refiere el art. 8 de la vigente LAR de 27 de noviembre de 2003 (RCL 2003, 2755), modificada por la de 8 de noviembre de 2005 (RCL 2005, 2347), lo que determinaría la inaplicación de dicha Ley y el sometimiento a la legislación común.

Sin embargo, es inconcebible que se fije como plazo el tiempo de recolección, lo que literalmente parece dar a entender que acabada la recolección (que puede durar muy poco con las modernas tecnologías) se extinguiría el contrato, lo que implicaría la recuperación de la posesión por la arrendadora quien se encargaría de preparar el cultivo, haciendo las operaciones propias del olivar tales como arado, poda, etc., etc., para luego volver a ceder el terreno para la recolección del año siguiente. Pero ello ni es lógico ni ha sido así, pues demostrado queda que ha sido la arrendataria la que ha hecho tales labores.

Hay que hablar, por tanto, de un arrendamiento plenamente integrado de la LAR aceptándose plenamente los razonamientos de la sentencia apelada en tal sentido. Ello conlleva la aplicación del art. 12 que establece una duración mínima de cinco años, siendo nula la estipulación de una duración menor». 
g) El art. 8 de la Ley 7/1998, de 13 de abril, de Condiciones Generales de Contratación, prevé que:

«1. Serán nulas de pleno derecho las condiciones generales que contradigan en perjuicio del adherente lo dispuesto en esta Ley o en cualquier otra norma imperativa o prohibitiva, salvo que en ellas se establezcan un efecto distinto para el caso de contravención.

2. En particular, serán nulas las condiciones generales que sean abusivas cuando el contrato se haya celebrado con un consumidor, entendiéndose por tales en todo caso las definidas en el art. 10 bis y disposición adicional primera de la Ley 26/1984, de 19 de julio, General para la Defensa de los Consumidores y Usuarios».

La Sentencia de la Audiencia Provincial de Valladolid de fecha 25 de enero de 2016 (JUR 2016/35617) explica que:

«Se trata de una condición general que entendemos ha de reputarse nula por abusiva conforme a lo dispuesto en el art. 8 de la Ley de Condiciones Generales de la Contratación (RCL 1998, 960), en relación con la disposición adicional primera, II, $14 .{ }^{a}$, de la Ley General para la Defensa de los Consumidores y Usuarios, en tanto impone una limitación o renuncia de los derechos del consumidor. Ello por cuanto la cláusula en cuestión comporta que cualquiera que sea el contenido de la liquidación certificada por el banco respecto de las cantidades dispuestas e impagadas con la tarjeta (comisiones, intereses remuneratorios y moratorios, etc.), el consumidor se hallará vinculado por ella sin posibilidad alguna de impugnarla o de intentar corregir cualquier error en que de adverso se pudiera haber incurrido, reconociéndole por anticipado plena eficacia en juicio sin posibilidad de cuestionarla siquiera en sede judicial. Se impone con ello una renuncia o limitación al consumidor de un derecho básico, cual es el de oponer ante la reclamación judicial del saldo las excepciones que procedieren caso de haberse realizado errónea o indebidamente la liquidación o cualquier tipo de cargo, obligándole a pasar ineludiblemente por dicha liquidación, fuera cual fuese su contenido, y renunciando por anticipado al derecho de defensa que al respecto le asiste. Vamos, por tanto, a acoger en este extremo el recurso y la demanda, con revocación en tal sentido de la sentencia apelada».

b) El art. 61 del Real Decreto Legislativo 1/1996, de 12 de abril, por el que se aprueba el Texto Refundido de la Ley de Propiedad Intelectual en relación con el contrato de edición, prevé que: 
«1. Será nulo el contrato no formalizado por escrito, así como el que no exprese los extremos exigidos en los apartados $3 .^{\circ}$ y $5 .^{\circ}$ del artículo anterior.

2. La omisión de los extremos mencionados en los apartados $6 .^{\circ}$ y $7 .^{\circ}$ del artículo anterior dará acción a los contratantes para compelerse recíprocamente a subsanar la falta. En defecto de acuerdo lo hará el juez atendiendo a las circunstancias del contrato, a los actos de las partes en su ejecución y a los usos».

La Sentencia de la Audiencia Provincial de Madrid de 3 de noviembre de 2005 (JUR 2006/18972) explica que:

«Entrando en el examen de lo pedido bajo el punto dos del suplico de la demanda, justificación documental del destino de aquella cantidad, tampoco procede acoger tal pedimento, pues aun cuando es cierto y no se controvierte que se suscribieren los dos contratos a que la demanda se refiere, que lo son de edición, definido en el art. 58 de la Ley de Propiedad Intelectual (RCL 1996, 1382) como aquel por el que el autor o sus derechohabientes ceden al editor, mediante compensación económica, el derecho a reproducir su obra y el de distribuirla, obligándose el editor a realizar estas operaciones por su cuenta y riesgo en las condiciones pactadas y con sujeción a lo dispuesto en la propia Ley; contrato formal, arts. 60 y 61 de la misma Ley, pues han de constar por escrito, bilateral y oneroso, con contenido de Derecho imperativo, arts. 60, 62 y 63, con referencia a los arts. 55, 57, 60 y 61, aun cuando dejando a las partes cierta capacidad dispositiva».

A la consecuencia de la contravención del TRLPI se refiere la Sentencia de la Audiencia Provincial de Madrid de fecha 13 de diciembre de 2004 (JUR 2005/47867), que se expresa de la siguiente manera:

«Siendo de destacar que, en todo caso, respecto al contrato de edición, el legislador sí precisaba expresamente la sanción de nulidad de no formalizarse por escrito el contrato (art. 61)».

i) El art. 6 de la Ley 29/1994, de 24 de noviembre, de Arrendamientos Urbanos, prevé que:

«Son nulas, y se tendrán por no puestas, las estipulaciones que modifiquen en perjuicio del arrendatario o subarrendatario las normas del presente título, salvo los casos en que la propia norma expresamente lo autorice». 
La Sentencia de la Audiencia Provincial de Las Palmas de fecha 18 de octubre de 2012 (JUR 2013/17774) lo aplica, indicando que:

«Llegados a este punto, procede estimar la pretensión de declaración de nulidad de la cláusula X del contrato de arrendamiento obrante en autos, pues en ella se estableció "que serán a cuenta del arrendatario todos y cada uno de los gastos de reparación necesarios que se precisara a los efectos de servir para el uso a que ha sido destinada", que fue el uso de vivienda exclusivamente según el contrato. En efecto, es necesario partir del art. 21 LAU (RCL 1994, 3272), a cuyo tenor: «El arrendador está obligado a realizar, sin derecho a elevar por ello la renta, todas las reparaciones que sean necesarias para conservar la vivienda en las condiciones de habitabilidad para servir al uso convenido, salvo cuando el deterioro de cuya reparación se trate sea imputable al arrendatario a tenor de lo dispuesto en los arts 1.563 y 1.564 del Código Civil (LEG 1889, 27). La obligación de reparación tiene su límite en la destrucción de la vivienda por causa no imputable al arrendador»; estableciendo el art. 21-4 que: "Las pequeñas reparaciones que exija el desgaste por el uso ordinario de la vivienda serán de cargo del arrendatario".

Quedó debidamente probado que las reparaciones de los defectos acreditados en el caso de autos constituyen reparaciones subsumibles en el art. 21-1 LAU, estando obligado legalmente a realizarlas el arrendador, no el arrendatario como se expresa en la cláusula, no constituyendo reparaciones subsumibles en el art. 21-4 LAU transcrito, las cuales serán de cargo del arrendatario. Tratándose de una estipulación que modifica en perjuicio del arrendatario las normas del título II de la LAU (el art. 21 está incluido en el mismo), resulta de aplicación el art. 6 LAU, a cuyo tenor serán nulas, y se tendrán por no puestas, las estipulaciones que modifiquen en perjuicio del arrendatario las normas del presente título (título II), salvo los casos en que la propia norma expresamente lo autorice, no existiendo tal autorización en el supuesto de autos; por el contrario, sí existe la posibilidad de pacto válido en los supuestos de los arts. 19, 20 o 25, párrafo último, de la LAU, que contemplan casos distintos del de autos. Por tanto, se aprecia la diferencia existente en relación con los arrendamientos para usos distintos del de vivienda de que trata el título III de la LAU, en los que rige el principio de la libertad de pacto, en tanto no se diga lo contrario en la normativa».

j) El art. 52.1 y 2 de la Ley 3/1987, de 2 de abril, General de Cooperativas, que dispone que:

«1. Podrán ser impugnados, según las normas y dentro de los plazos establecidos en este artículo, los acuerdos de la Asamblea General que sean contrarios a la Ley, que se opongan a los Estatutos o lesionen, 
en beneficio de uno o varios socios, asociados o terceros, los intereses de la cooperativa.

No procederá la impugnación de un acuerdo social cuando haya sido dejado sin efecto o sustituido válidamente por otro.

2. Serán nulos los acuerdos contrarios a la Ley. Los demás acuerdos a que se refiere el número anterior serán anulables.

La Sentencia que estime la acción de nulidad o anulabilidad de un acuerdo social producirá efectos frente a todos los socios y asociados, pero no afectará a los derechos adquiridos de buena fe por los terceros a consecuencia del acuerdo impugnado».

La Sentencia del Tribunal Supremo de fecha 21 de octubre de 1982 (RJ 1982/5568) declara, en relación con la anterior Ley que establecía la misma previsión, que:

«Con base en lo normado en el núm. 1. del art. 27 de la precitada Ley General de Cooperativas de 19 de diciembre de 1974, que posibilita la solicitud de declaración de nulidad de pleno derecho de los acuerdos sociales contrarios a la Ley o a los Estatutos bien en juicio declarativo ordinario o ya por el cauce procesal previsto en el núm. 2 del mismo precepto legal, y que ejercitado por el primero de dichos remedios procesales, o sea, por el cauce del juicio declarativo ordinario, no viene sometida la correspondiente acción al plazo de caducidad de cuarenta días a que alude el núm. 2 del referido art. 27 de la Ley General de Cooperativas, que se contrae exclusivamente a los acuerdos que, en beneficio de uno o varios miembros contra los intereses de la cooperativa, y no a los supuestos de acuerdos sociales contrarios a la Ley o a los Estatutos, cual es el atacado en la litis de que este recurso dimana, afectante al principio de igualdad que tanto la Ley reguladora de la materia de cooperativas como los Estatutos de la nominada "Ciudad Encantada" establecen como de riguroso e ineludible cumplimiento, y que omitido determina sanción de nulidad de pleno derecho, que como de tal índole no puede quedar enervado por el hecho de que por mayoría se hubiese adoptado acuerdo en contra en Junta General Extraordinaria, puesto que siendo la esencia de la nulidad de pleno derecho, también denominada radical, que se produce ipso iure, dado que los actos contrarios a la Ley son nulos en sí, en modo alguno puede producir ni produce el efecto pretendido por el que la baya dado origen, $y$, por tanto, no engendra efecto alguno en contra de aquel al que perjudique que no sea, según reiterada doctrina jurisprudencial de la que es claro exponente la Sentencia de esta Sala de 3 de enero de 1947 (RJ 1947/5), la de dar base a la correspondiente acción de nulidad que destruya la apariencia de realidad o validez del acto que haya dado vida al reputado radical o absolutamente nulo, lo que tanto quiere decir que el acuerdo mayorita- 
rio adoptado en Junta General Extraordinaria producido en el presente caso creando el expresado acto con tal alcance de nulidad no puede ser eficaz para subsanar éste, en ortodoxa aplicación del principio de que quod nullum est, nullum producit effectum, conducente a que el Derecho considere al acto como no realizado, y concretamente con carencia de efectos específicos».

\section{Convalidación de actos nulos}

La mayoría de la doctrina entiende que el contrato nulo no se puede convalidar de ninguna manera. Sin embargo, ello no se considera exactamente así por todos los autores. El término convalidación se utiliza para designar la sanación de un contrato meramente impugnable por desaparición de la causa de impugnabilidad. Sin embargo, la hipótesis de sanación del contrato impugnable, utilizando la terminología de nuestro Código Civil, debe ser considerada como confirmación y debe, por consiguiente, reservarse el nombre de convalidación para aquellos supuestos ciertamente excepcionales en los cuales, pese a la nulidad radical del contrato nulo, se admite rectificación o regularización ${ }^{8}$.

En principio parecen actos convalidables, pese a su inicial nulidad, aquellos respecto de los cuales su autor carecía del poder de legitimación necesario para afectar a la esfera de intereses contemplada por el contrato. La posterior aceptación del negocio por el titular de dicha esfera de intereses (ratificación) permite convalidar el contrato. Desde este punto de vista, el art. 1.259 , párrafo $2 .^{\circ}$, dice que el contrato celebrado a nombre de otro por quien no tenga su autorización o representación legal será nulo, a no ser que lo ratifique la persona a cuyo nombre se otorgó antes de ser revocado por la otra parte contratante?

En concreto, Federico de Castro y Bravo ${ }^{10}$ cita como casos de convalidación admitidos respecto a los negocios incompletos: a) casos en que se concede a un extraño al negocio la facultad de convalidarlo, apropiándose del negocio mediante la ratificación (arts. 1.259, 1.727, 1.892 y 1.893); b) casos en que el negocio requiere para su validez una autorización posterior (por ejemplo, arts. 269 y 597) o una aprobación formal (administrativa o judicial) que venga a subsanar la nulidad.

\footnotetext{
${ }^{8}$ L. Díez Picazo, Fundamentos del Derecho Civil Patrimonial, t. I, Introducción: teoría del contrato, op. cit., p. 458.

9 Ibid.

${ }^{10}$ F. de Castro y Bravo, El negocio jurídico, op. cit., pp. 485 y 486.
} 
Otro de los puntos en que la doctrina tradicional viene admitiendo la posibilidad de convalidación se encuentra en los negocios dispositivos cuando el transmitente carece del necesario poder de disposición. Cuando el disponente adquiere posteriormente el dominio, el contrato queda convalidado. Se habla en estos casos de una convalidación del acto de disposición por la sobrevenida adquisición del dominio.

La convalidación cabe también en aquellos casos en que a través de la renovación del contrato nulo las partes pueden reconstruir la reglamentación de intereses proyectada en el contrato anterior. En el mismo sentido cabe hablar también de convalidación en todos aquellos casos en que, siendo posible todavía el otorgamiento de la forma documental solemne exigida para la validez, sea ésta llenada.

Por último, cabe hablar también de convalidación de los contratos nulos en los casos llamados de conversión. La conversión del contrato nulo es otra de las manifestaciones prácticas del principio de favor del contrato y es el instrumento jurídico que permite que un contrato nulo, pero que contiene los requisitos de validez de otro contrato, sea eficaz como este otro contrato por voluntad de las partes del contrato nulo que hubiesen querido el nuevo contrato si hubiesen conocido la nulidad del contrato originario.

\section{DOCTRINA GENERAL SOBRE LA ANULABILIDAD}

La idea de anulabilidad surge, según la doctrina ${ }^{11}$, cuando se comprueba que no es conveniente que toda vulneración de una norma deba ser sancionada con la nulidad. Se considera que hay situaciones intermedias en las que, aunque se acredite la violación de una norma, es aconsejable establecer otra modalidad distinta de ineficacia cuando la falta de efectos se supedita a que el perjudicado por el acto contrario a la ley lo impugne. Esta idea de una categoría intermedia de ineficacia es aceptada por el movimiento codificador europeo del siglo XIX, aunque no siempre los Códigos han distinguido nítidamente la nulidad de la anulabilidad (ejemplos de esta falta de claridad son tanto el Código Civil francés como el español, en los que es desconocido el empleo del término y en los que la palabra nulidad es utilizada en el doble sentido de nulidad radical o de anulabilidad).

11 E. Serrano Alonso y E. Serrano Gómez, Manual de Derecho de Obligaciones y Contratos, t. II, vol. 1, Teoría General del Contrato, op. cit., pp. 135 y ss. 
Esta situación explica que Federico de Castro haya podido afirmar que la figura del negocio o contrato anulable resulta complicada y contradictoria, no encontrando justificación ni en la voluntad expresa o presunta de las partes, ni en el juego natural de las normas sancionadoras. La particularidad más llamativa del concepto de anulabilidad se obtiene de su comparación con la nulidad del contrato. En efecto, el contrato anulable es un contrato existente y válido, porque reúne los requisitos de existencia exigidos por el art. 1.261 y por ello es plenamente eficaz desde el momento de su perfección, pero por presentar ciertos defectos está amenazado de que sus efectos cesen. En otras palabras, el contrato que es calificado como anulable es un contrato provisionalmente eficaz en la medida en que el titular de la acción la ejercite o no. La eficacia definitiva del contrato anulable depende del titular de la acción de impugnación: mientras no se impugna equivale a un contrato válido, pero si es impugnado sus consecuencias son semejantes a las que produce el contrato nulo; esa identidad de consecuencias finales entre el contrato nulo y anulable ha llevado a parte de la doctrina a cuestionar la utilidad de la distinción. Sin embargo, a pesar de todas estas objeciones, se trata de un tipo de ineficacia generalmente aceptada por la doctrina.

La anulabilidad, sigue diciendo la doctrina, se caracteriza inicialmente por ser un medio jurídico puesto por la ley a disposición de determinadas personas para facilitar la protección de concretos intereses que se consideran dignos de la tutela jurídica, de manera que se deja al arbitrio de ellas la decisión final en torno a si el contrato va a ser o no válido. Se sigue de ello una clara restricción de la acción de anulación y, al mismo tiempo, una cierta limitación temporal en el ejercicio de ese poder jurídico. En ello existe consenso en la doctrina.

Los contratos anulables han de ser contratos en los que concurran los requisitos generales de éstos, aunque adolezcan de alguno de los vicios que los invaliden con arreglo a la Ley. El Código Civil dice expresamente que para que pueda ejercitarse la acción de anulación, o demandarse de otro modo, no es necesaria la existencia de lesión (art. 1.300). El contrato no se anula por causa de lesión, porque el tratamiento jurídico de las posibles lesiones pertenece a la categoría de la rescisión (arts. 1.290 a 1.299). La persona favorecida con la protección del ordenamiento jurídico puede demandar la anulación cualesquiera que sean los motivos o intereses que la guíen para ello. 


\section{Supuestos concretos de anulabilidad}

Las causas de anulación de los contratos son en nuestro Código Civil fundamentalmente las siguientes:

a) La falta de una plena capacidad de obrar. Son anulables los contratos llevados a cabo por los incapaces de obrar o por las personas que poseen una capacidad de obrar limitada, así como aquellos en que no se hayan reunido los suplementos o complementos de capacidad necesarios.

b) La existencia de los llamados vicios de la voluntad. Por esta razón son anulables los contratos que hayan sido celebrados con error esencial excusable, dolo causante, intimidación y miedo grave.

c) La falta del consentimiento del otro cónyuge, cuando sea necesario de acuerdo con el régimen jurídico de la sociedad conyugal, para los actos realizados por uno de los cónyuges (art. 1.322, párrafo $1 .^{\circ}$, frente al párrafo $2 .^{\circ}$, que declara nulos los actos a título gratuito realizados por un cónyuge sin el consentimiento del otro).

La doctrina mayoritaria considera que las causas de anulabilidad contempladas en el Código Civil han de considerarse exhaustivas y, en consecuencia, no cabe deducir otras por vía analógica o interpretativa. Se considera, por tanto, que la regla general es la nulidad, siendo la anulabilidad un régimen, si no excepcional, sí al menos especial. No se puede desconocer, sin embargo, como ponen de manifiesto algunos autores, la labor interpretativa efectuada por el Tribunal Supremo.

\section{Confirmación de actos anulables}

El Código Civil dice, en su art. 1.309, que la acción queda extinguida desde el momento en que el contrato ha sido confirmado válidamente $y$, posteriormente, regula algunos aspectos de esta figura jurídica. Ello es una consecuencia de la forma de configurar y articular la anulabilidad. Puesto que existe una facultad y una medida de protección de los intereses de una de las partes del contrato, a cuyo arbitrio se deja la decisión final en orden a la validez o invalidez del mismo, resulta claro que el contrato anulable puede ser sanado. Es a esta sanación a lo que nuestro Código Civil denomina confirmación.

La confirmación puede considerarse como uno de los tipos o manifestaciones de una categoría científica más amplia o extensa que es la con- 
validación. Ésta, que no es reconocida de forma expresa en ningún texto positivo, es aceptada por la doctrina. La confirmación puede ser definida como el acto unilateral realizado por quien puede hacer valer la ineficacia del contrato en virtud del cual queda sanado y produce todos sus efectos como si nunca hubiese estado viciado ${ }^{12}$.

\section{CASOS CONCRETOS DE NEGOCIOS JURÍDICOS INCOMPLETOS POR FALTA DE AUTORIZACIÓN PREVIA PREVISTA EN LAS DISPOSICIONES LEGALES: CONSECUENCIAS Y POSIBILIDAD O NO DE CONVALIDARLOS}

\section{En el ámbito del Derecho civil}

A. Los negocios jurídicos realizados por los representantes legales de los bijos menores de edad sin la pertinente autorización judicial que es exigible conforme a lo dispuesto en el art. 166 del Código Civil

El art. 166 del Código Civil dispone que:

«Los padres no podrán renunciar a los derechos de que los hijos sean titulares, ni enajenar o gravar sus bienes inmuebles, establecimientos mercantiles o industriales, objetos preciosos y valores mobiliarios, salvo el derecho de suscripción preferente de acciones, sino por causas justificadas de utilidad o necesidad y previa la autorización del juez del domicilio, con audiencia del Ministerio Fiscal.

Los padres deberán recabar autorización judicial para repudiar la herencia o legado deferidos al hijo. Si el juez denegase la autorización, la herencia sólo podrá ser aceptada a beneficio de inventario.

No será necesaria autorización judicial si el menor hubiese cumplido dieciséis años y consintiere en documento público, ni para la enajenación de valores mobiliarios, siempre que su importe se reinvierta en bienes o valores seguros».

La Sentencia del Tribunal Supremo de 28 de octubre de 2014 (RJ 2014/5847) trata el caso de un contrato por el que el padre de unos hijos menores de edad vendió la finca de éstos en su propio nombre y en

${ }^{12}$ Ibid., pp. 149 y ss. 
el de sus hijos menores sin haber solicitado la autorización judicial preceptiva, en el que se plantea, como cuestión de fondo, la naturaleza y alcance de la ineficacia derivada del referido contrato.

La referida Sentencia del Tribunal Supremo mantiene que:

«En este sentido, y desde la perspectiva metodológica, debe señalarse, en primer lugar, que el análisis del régimen que resulte aplicable en aquellos supuestos en donde el ordenamiento jurídico no dé una respuesta técnica y concreta al respecto no puede quedar reconducido a un planteamiento estático y dogmático de la cuestión consistente en la mera adscripción del supuesto a las categorías conceptuales de ineficacia desarrolladas doctrinalmente. Por el contrario, debe precisarse que el método de análisis a emplear es consustancialmente dinámico y flexible, conforme a las peculiaridades que presente el caso objeto de examen; de forma que el contenido y alcance de la ineficacia se adapta a la naturaleza y función que presente el fenómeno jurídico en cuestión y la relevancia de los bienes e intereses jurídicos que sean objeto de protección o de valoración, todo ello conforme a la finalidad perseguida por la norma o por la aplicación de los propios principios generales del Derecho.

En segundo lugar, también debe puntualizarse que, precisamente en la línea de proyección de los principios generales del Derecho, la reciente doctrina jurisprudencial de esta Sala [STS de 15 de enero de 2013, núm. 827/2012 (RJ 2013, 2276)], conforme al desenvolvimiento de los principales textos de armonización y desarrollo del Derecho contractual europeo, ha declarado "que la conservación de los actos y negocios jurídicos (favor contractus) se erige como un auténtico principio informador de nuestro sistema jurídico que comporta, entre otros extremos, el dar una respuesta adecuada a las vicisitudes que pueda presentar la dinámica contractual desde la preferencia y articulación de los mecanismos que anidan en la validez estructural del contrato y su consiguiente eficacia funcional, facilitando el tráfico patrimonial y la seguridad jurídica." Doctrina jurisprudencial que tiene una coherente aplicación sistemática en el campo de nuestro Derecho patrimonial; casos, entre otros, del reforzamiento de los principios de favor testamenti y favor partitionis en el ámbito del Derecho de sucesiones [SSTS de 30 de octubre de 2012, núm. 624/2012 (RJ 2013, 2274); de 20 de marzo de 2013, núm. 140/2013 (RJ 2013, 7291), y de 4 de enero de 2013, núm. 785/2013 (RJ 2013, 4590)]; de su aplicación al ámbito de la contratación seriada y protección del consumidor [STJUE de 30 de abril de 2014 y STS de 8 de septiembre de 2014, núm. 464/2014 (RJ 2014, 4660)], o de su incidencia en el efecto modificativo de la relación contractual en aplicación de la cláusula rebus sic stantibus ("estando así las cosas") [SSTS de 30 de 
junio de 2014, núm. 333/2014 (RJ 2014, 3526), y de 17 de enero de 2013, núm. 820/2013 (RJ 2013, 1819)].

Aplicación de la doctrina jurisprudencial expuesta al supuesto de enjuiciamiento.

3. Régimen de ineficacia contractual del art. 166 del Código Civil (LEG 1889, 27).

La doctrina jurisprudencial expuesta, llevada al supuesto de enjuiciamiento, exige realizar las siguientes precisiones que conducen a la desestimación del motivo planteado.

En esta línea, la Sentencia de esta Sala de 22 de abril de 2010, núm. 225/2010 (RJ 2010, 2380), que es tomada como referente por la sentencia de la Audiencia, resulta ilustrativa acerca de la falta de un pronunciamiento claro y uniforme de nuestra doctrina jurisprudencial sobre la eficacia del acto realizado por el titular de la patria potestad sin la pertinente autorización judicial.

En este contexto interpretativo (Fundamento de Derecho 4. ${ }^{\circ}$ de la Sentencia citada) la doctrina jurisprudencial ha mantenido tres posturas conceptuales diversas en el análisis del fenómeno jurídico coincidentes, no obstante, con el anterior método tradicional de la mera adscripción del supuesto enjuiciado en el elenco de las categorías doctrinales relativas a la ineficacia contractual. De esta forma, la doctrina jurisprudencial se ha pronunciado en orden a la nulidad radical del acto o negocio realizado, ya por la inexistencia del mismo o bien por ser contrario a una norma imperativa, a su nulidad, matizada por razón de ser un acto realizado con extralimitación del poder concedido y, en su caso, a la solución del régimen de la anulabilidad con la posible confirmación del acto por el transcurso del plazo dispuesto por la norma.

La incertidumbre de este contexto interpretativo, por otra parte explicable dada la complejidad conceptual y metodológica del tema y el insuficiente tratamiento técnico de la cuestión por la dogmática codificadora, tiende a resolverse si, como hace la sentencia citada (Fundamento 5..$^{\circ}$ y aquí se puntualiza, se procede a invertir la perspectiva de análisis en atención a un planteamiento dinámico y flexible de la ineficacia derivada que adopta su contenido y alcance a los criterios anteriormente expuestos. En efecto, desde esta perspectiva, y fuera de los supuestos en el que el propio objeto del contrato resulte contrario al orden público, caso de la STS de 5 de febrero de 2013, núm. 26/2013 (RJ 2013, 928), se comprende como desde la finalidad tuitiva de la norma, que no es otra que tutelar el interés patrimonial del menor, y de la naturaleza y función de la autorización judicial, que no cumple la función de ser un complemento de la capacidad del menor, casos de la emancipación o de la curatela, sino que es un elemento o condición del acto de disposición, la razón de la ineficacia derivada 
se aleja de los parámetros propios de una suerte de ineficacia absoluta, de carácter estructural e insanable, para recalar, más bien o ajustadamente, en una ineficacia funcional y relativa, propia de los contratos o negocios jurídicos de ejecución progresiva o incompletos, que generan una eficacia provisional o claudicante hasta que se produce su eficacia definitiva, bien por el propio cumplimiento de la circunstancia o condición, bien por la propia convalidación del afectado mediante su ratificación expresa o tácita y, en su caso, por el transcurso del plazo establecido. Todo ello conforme a la interpretación sistemática del precepto, particularmente de su correlación con el art. 1.259 del Código Civil y del principio de conservación de los actos y negocios jurídicos, anteriormente expuesto. Extremos a los que llama la perspectiva de análisis propuesta».

En definitiva, el Tribunal Supremo considera que en los casos de negocios jurídicos para los que el indicado precepto del Código Civil exige previa autorización judicial, sin que se haya obtenido la misma, se está ante negocios jurídicos incompletos que se podrían convalidar, según la sentencia, por la ratificación del afectado expresa o tácita y, en su caso, por el transcurso del plazo establecido, y se entiende que también se podrían convalidar, aunque la sentencia no lo contempla, por la autorización judicial posterior.

\section{B. Los negocios jurídicos realizados por el tutor sin la necesaria autorización judicial}

El art. 271 del Código Civil dispone que:

«El tutor necesita autorización judicial:

1. Para internar al tutelado en un establecimiento de salud mental o de educación o formación especial.

2. Para enajenar o gravar bienes inmuebles, establecimientos mercantiles o industriales, objetos preciosos y valores mobiliarios de los menores o incapacitados, o celebrar contratos o realizar actos que tengan carácter dispositivo y sean susceptibles de inscripción. Se exceptúa la venta del derecho de suscripción preferente de acciones.

3. Para renunciar derechos, así como transigir o someter a arbitraje cuestiones en que el tutelado estuviese interesado.

4. ${ }^{\circ}$ Para aceptar sin beneficio de inventario cualquier herencia o para repudiar ésta o las liberalidades.

5. Para hacer gastos extraordinarios en los bienes.

6. Para entablar demanda en nombre de los sujetos a tutela, salvo en los asuntos urgentes o de escasa cuantía. 
7..$^{\circ}$ Para ceder bienes en arrendamiento por tiempo superior a seis años.

8. Para dar y tomar dinero a préstamo.

9. Para disponer a título gratuito de bienes y derechos del tutelado.

$10 .^{\circ}$ Para ceder a terceros los créditos que el tutelado tenga contra él, o adquirir a título oneroso los créditos de terceros contra el tutelado».

La Sentencia del Tribunal Superior de Justicia de Madrid de 15 de septiembre de 2015 (JUR 2015/241841) se refiere a un supuesto en el que el tutor había sometido a arbitraje, sin la previa y preceptiva autorización judicial, cuestiones en las que indudablemente el tutelado estaba interesado, indicando que:

«En este punto no cabe sino aplicar la clara doctrina establecida por el Pleno de la Sala Primera en su Sentencia de 22 de abril de 2010 (ROJ 2561/2010), que, en aplicación específica a los actos del tutor realizados sin autorización judicial, se recoge, por todas, en la STS de 8 de julio de 2010 (ROJ 4705/2010), cuyos FFJ 3. ${ }^{\circ}$ y $4 .^{\circ}$ proclaman:

"Es cierto que tanto la jurisprudencia como la doctrina han ofrecido distintas soluciones a un problema, el del tipo de ineficacia que afecta a los actos del tutor efectuados sin autorización judicial, que carece de regulación en el Código Civil (LEG 1889, 27). La Sentencia del pleno de esta Sala de 22 de abril de 2010, después de resumir las diferentes posturas mantenidas en relación a la validez de los actos del padre realizados sin autorización judicial, ha interpretado esta falta de normativa en el sentido de que 'se trata de integrar el art. 166 CC con lo que dispone el art. 1.259.1 CC cuando dice que 'ninguno puede contratar a nombre de otro [...] sin que tenga por la ley su representación legal'. De donde surgen los siguientes argumentos favorables a la ineficacia relativa del acto en el sentido que luego se explicitará: a) el art. $166 \mathrm{CC}$ es una norma imperativa que coincide con lo dispuesto en el art. 1.259 CC y, a salvo la ratificación, su incumplimiento lleva a la aplicación del art. 6.3 CC, es decir, la nulidad del acto; $b$ ) el fin de protección de la norma contenida en el art. 166 CC es la salvaguardia del interés de los menores, que no pueden actuar por sí mismos y que pueden encontrarse en situaciones de desprotección cuando alguien contrata en su nombre y obliga sus patrimonios sin el preceptivo control, ya que deberán asumir las correspondientes deudas; c) la actuación de los padres siempre debe tener como finalidad el interés del menor, tal como dispone el art. 154.2 CC; $d$ ) el propio art. 1.259 CC se añade a esta argumentación, según la doctrina y alguna jurisprudencia ya citada, porque va a permitir que el contrato pueda ser objeto de ratificación por el propio interesado cuando sea favorable a sus intereses. De aquí que deba aplicarse lo dispuesto en el art. 1.259 CC, porque la autorización judicial para la realización del acto por el representante legal cuando la 
ley lo requiera tiene naturaleza imperativa en el Código Civil y no es un simple complemento del acto a realizar. De acuerdo con el art. 166 CC, la representación de los padres como representantes legales no alcanza los actos enumerados en el art. 166 CC. Las excepciones se encuentran en que los actos de disposición tengan causas de utilidad justificadas y se deben realizar previa autorización judicial con audiencia del Ministerio Fiscal. La autorización judicial no es un complemento de capacidad como ocurre en la emancipación o en la curatela, sino que es un elemento del acto de disposición, puesto que los padres solos no lo ostentan. Y todo ello para obtener la protección de los intereses del menor [...] El acto realizado con falta de poder, es decir, sin los requisitos exigidos en el art. 166 CC, constituye un contrato o un negocio jurídico incompleto que mantiene una eficacia provisional, estando pendiente de la eficacia definitiva que se produzca por la ratificación del afectado, que puede ser expresa o tácita. Por tanto, no se trata de un supuesto de nulidad absoluta, que no podría ser objeto de convalidación, sino de un contrato que aún no ha logrado su carácter definitivo al faltarle la condición de la autorización judicial exigida legalmente, que deberá ser suplida por la ratificación del propio interesado, de acuerdo con lo dispuesto en el art. 1.259.2 CC, de modo que, no siéndolo, el acto será inexistente”.

Esta doctrina debe aplicarse también a los casos de actuación del tutor sin autorización judicial, porque obedece a la misma finalidad que la ya explicada en relación a los padres titulares de la patria potestad. En efecto, el art. 271 CC (LEG 1889, 27) enuncia los actos que el tutor no puede llevar a cabo sin autorización judicial y el art. 272 CC permite obtenerla a posteriori únicamente en el caso de la partición hereditaria. La jurisprudencia y la doctrina se han planteado para los actos no autorizados del tutor las mismas dudas que ya se han señalado respecto del tipo de ineficacia que afecta a los actos de disposición del titular de la potestad efectuados sin autorización judicial, y por ello debe aplicarse la doctrina de la Sentencia de 22 de abril de 2010 también a este caso. En consecuencia, debe declararse la nulidad del contrato de opción de compra y venta de las acciones que retuvieron los incapaces en la liquidación de su participación en las empresas del grupo familiar $[\ldots]$

La doctrina contenida en estas sentencias es perfectamente aplicable al caso, habida cuenta de la inexistencia de normas específicas en contrario - v. gr. arts. 1.387 a 1.389 CC sobre la eficacia de los actos de disposición relativos a bienes gananciales efectuados por el esposo tutor sin autorización judicial [en este sentido, STS de 23 de septiembre de 2010, FJ 5. ${ }^{\circ}$ (ROJ 4683/2010)].

Por lo expuesto, el motivo de anulación debe ser estimado, precisando que el convenio arbitral suscrito es inválido ex art. 271.3. ${ }^{\circ} \mathrm{CC}$ en conexión con el art. 41.1.a) LA, sin que conste probada ratificación alguna, ni se haya 
suscitado, dada la incapacidad del pupilo, la posibilidad de convalidación posterior de ninguna clase».

En definitiva, el Tribunal Superior de Justicia de Madrid también admite que los negocios jurídicos realizados por los tutores sin la previa y necesaria autorización judicial se pueden convalidar por la autorización posterior en los casos expresamente contemplados.

\section{Los actos de disposición relativos a bienes gananciales efectuados por el esposo tutor sin autorización judicial}

El art. 1.389 del Código Civil dispone que:

«El cónyuge en quien recaiga la administración en virtud de lo dispuesto en los dos artículos anteriores tendrá para ello plenas facultades, salvo que el juez, cuando lo considere de interés para la familia, y previa información sumaria, establezca cautelas o limitaciones.

En todo caso, para realizar actos de disposición sobre bienes inmuebles, establecimientos mercantiles, objetos preciosos o valores mobiliarios, salvo el derecho de suscripción preferente, necesitará autorización judicial».

La Sentencia del Tribunal Supremo de 23 de septiembre de 2010 (JUR 2010/558) declara que:

«A continuación debemos plantear cuál es el tipo de ineficacia que corresponde a los actos de disposición sobre bienes inmuebles efectuados por el cónyuge capaz sin la preceptiva autorización. Debe advertirse que en el presente supuesto no puede aplicarse la doctrina contenida en la Sentencia del Pleno de esta Sala de 22 de abril de 2010 (RJ 2010, 2380) y en la de 8 de julio de 2010 que la aplica, que declaran la nulidad de los actos de disposición efectuados por el titular de la patria potestad y por el tutor sin la autorización judicial. La imposibilidad de aplicar la doctrina contenida en estas sentencias deriva de la existencia de normas específicas y expresas relativas a la ineficacia de los actos de disposición relativos a bienes gananciales efectuados por el esposo tutor sin autorización judicial contenidas en el citado art. 1.389.2 CC.

En los casos resueltos en las citadas sentencias se parte de la base contraria a la que existe respecto de la disposición de los bienes gananciales, porque el Código Civil contiene una norma específica reguladora de la ineficacia de estos actos o contratos que hay que aplicar necesariamente cuando se trata de disposición de bienes gananciales sin las correspondientes auto- 
rizaciones. Se trata de la norma contenida en el art. 1.322 CC, que dice que cuando la ley exija para un acto de administración que un cónyuge actúe con el consentimiento del otro, "los realizados sin él y que no hayan sido expresa o tácitamente confirmados podrán ser anulados a instancia del cónyuge cuyo consentimiento se haya omitido". El supuesto contemplado en el art. 1.398.2 CC está incluido en este supuesto, porque obedece a la misma razón.

Por tanto, la ineficacia de los actos otorgados por el cónyuge tutor sin autorización judicial no es la nulidad general de los arts. 1.259 y 4 CC, como ocurre en la disposición por el padre o el tutor de bienes de sus hijos o pupilos sin la autorización judicial, sino la de los arts. 1.389 y 1.322 CC, que establecen un tipo de ineficacia concreto para la disposición de los gananciales sin la preceptiva autorización».

En este supuesto, aunque el Tribunal Supremo no entra a considerar esta cuestión, también se entiende que sería posible la convalidación del negocio jurídico de disposición realizado sin la previa y preceptiva autorización judicial, que sería un negocio jurídico incompleto por la posterior autorización judicial.

\section{En el ámbito del Derecho administrativo}

A. Falta de autorización previa en el supuesto de subcontratación de actividades subvencionadas en materia de subvenciones públicas

La subcontratación por los beneficiarios de las actividades subvencionadas en materia de subvenciones públicas se regula en el art. 29 de la Ley 38/2003, de 17 de noviembre, General de Subvenciones (en adelante LGS).

El apartado 1 de dicho art. 29 LGS establece que «a efectos de esta ley, se entiende que un beneficiario subcontrata cuando concierta con terceros la ejecución total o parcial de la actividad que constituye el objeto de la subvención. Queda fuera de este concepto la contratación de aquellos gastos en que tenga que incurrir el beneficiario para la realización por sí mismo de la actividad subvencionada».

José Pascual García ${ }^{13}$ explica, en relación con este apartado, que la ley se inspira en el principio de que la realización de la actividad subvencionada es obligación personalísima del beneficiario, dado que la concesión

13 J. Pascual García, Las subvenciones públicas. Legislación comentada, formularios y procedimientos, Madrid, Boletín Oficial del Estado, 2007, pp. 148 y ss. 
se hace intuitu personae. La subcontratación de la actividad subvencionada (expresión inadecuada, pues el subvencionado no es un contratista que pueda subcontratar) implica la traslación a un tercero de la realización de la actividad en lugar de hacerla por sí mismo. No parece, sin embargo, que la ley pretenda llevar el intuitu personae hasta el extremo de exigir la ejecución por sí de actividades o prestaciones ajenas a la actividad habitual del beneficiario, cuando no se hayan tenido en cuenta expresamente en las bases reguladoras o en la convocatoria sus condiciones personales a estos efectos. A los gastos derivados de la contratación de actividades o prestaciones que no entren en el concepto de «subcontrata» les serán de aplicación las prescripciones del art. 31 LGS sobre gastos subvencionables.

En este sentido, el art. 68.1 del Real Decreto 887/2006, de 21 de julio, por el que se aprueba el Reglamento de la Ley 38/2003, de 17 de noviembre, General de Subvenciones (en adelante RLGS), dispone que: «La realización de la actividad subvencionada es obligación personal del beneficiario sin otras excepciones que las establecidas en las bases reguladoras, dentro de los límites fijados en el art. 29 LGS y en este Reglamento».

El beneficiario únicamente podrá subcontratar, total o parcialmente, la actividad cuando la normativa reguladora de la subvención así lo prevea. La actividad subvencionada que el beneficiario subcontrate con terceros no excederá del porcentaje que se fije en las bases reguladoras de la subvención. En el supuesto de que tal previsión no figure, el beneficiario podrá subcontratar hasta un porcentaje que no exceda del 50 por 100 del importe de la actividad subvencionada. En ningún caso podrán subcontratarse actividades que, aumentando el coste de la actividad subvencionada, no aporten valor añadido al contenido de la misma (art. 29.2 LGS).

De igual manera, el art. 68.1 RGLS prevé que «si las bases reguladoras permitieran la subcontratación sin establecer límites cuantitativos, el beneficiario no podrá subcontratar más del 50 por 100 del importe de la actividad subvencionada, sumando los precios de todos los subcontratos».

Cuando la actividad concertada con terceros exceda del 20 por 100 del importe de la subvención y dicho importe sea superior a 60.000 euros, la subcontratación estará sometida al cumplimiento de los siguientes requisitos:

a) Que el contrato se celebre por escrito.

b) Que la celebración del mismo se autorice previamente por la entidad concedente de la subvención en la forma que se determine en las bases reguladoras (art. 29.3 LGS). 
Se aprecia, por tanto, que el art. 29.3 LGS somete la subcontratación de la actividad subvencionada al cumplimiento del requisito de la autorización previa por la entidad concedente de la subvención en la forma que se determine en las bases reguladoras cuando la actividad concertada con terceros exceda del 20 por 100 del importe de la subvención y dicho importe sea superior a 60.000 euros.

En un supuesto concreto se suscribió un convenio de colaboración entre un ministerio y una fundación para regular las condiciones y compromisos a que se sometía la subvención nominativa otorgada a la fundación por el importe que figuraba en los Presupuestos Generales del Estado correspondientes, de acuerdo con lo dispuesto en los arts. 22.2.a) y 28 LGS, y 65 RLGS. Convenio de colaboración en el que se contemplaba la posibilidad de que la fundación pudiera subcontratar, total o parcialmente, la ejecución de las actividades subvencionables con sujeción a lo dispuesto en el art. 29 LGS, incluyendo la previa autorización de la subcontratación en los casos en que fuera necesaria. Se preveía que la subcontratación podría alcanzar el 100 por 100 de las actividades subvencionadas, quedando excluida la de aquellas actuaciones para cuya realización la fundación contara con medios propios adecuados y suficientes.

Sin embargo, la fundación había procedido a la subcontratación de las actividades subvencionadas sin solicitar la autorización previa que exige el art. 29 LGS, por lo que se entiende que la actividad concertada con terceros fue superior al 20 por 100 del importe de la subvención y que dicho importe fue superior a 60.000 euros. No aparecía constatado que la subcontratación se hubiera realizado con personas con las que no se pudiera concertar la ejecución total o parcial de la actividad subvencionada, por lo que se parte del presupuesto de que se efectuó con personas con las que sí se podía concertar la ejecución total o parcial de la actividad subvencionada.

La fundación era, de acuerdo con sus estatutos, una organización privada de naturaleza fundacional, sin fin de lucro, cuyo patrimonio se hallaba afectado, de modo duradero, a la realización de los fines de interés general propios de la institución. De los estatutos resultaba que no era una fundación que se hubiese constituido con una aportación mayoritaria, directa o indirecta, de una o varias entidades integradas en el sector público, de acuerdo con lo dispuesto en el art. 3.1 TRLCSP, o cuyo patrimonio fundacional, con carácter de permanencia, estuviera formado en más de un 50 por 100 por bienes o derechos aportados o cedidos por las referidas entidades, por lo que se considera que no formaba parte del sector público. 
En consecuencia, al haberse celebrado el contrato por el que se concertó con terceros la realización de la actividad que constituye el objeto de la subvención por una fundación que no pertenecía al sector público, dicho contrato no estaba sometido al TRLCSP, como se deduce de su art. 2.1.

El contrato por el que se concertó con terceros la realización de la actividad que constituye el objeto de la subvención era un contrato privado que se hallaba sujeto a las normas de Derecho privado y resulta que se había realizado sin la previa autorización en el supuesto en que ésta era necesaria.

Sin embargo, en este supuesto se entiende que, tal y como se regula la subcontratación en la LGS, sería aplicable más bien la LPAC (art. 52.4), que permite la convalidación posterior y, en cualquier caso, si el incumplimiento de esta obligación o compromiso del beneficiario con motivo de la concesión de la subvención pudiera haber afectado o se hubiera referido al modo en que se habían de conseguir los objetivos, realizar la actividad, ejecutar el proyecto o adoptar el comportamiento que fundamentara la concesión de la subvención, podría haberse entendido que concurría causa de reintegro [art. 37.1.f) LGS].

\section{B. Falta de autorización previa del Protectorado en caso de autocontratación en materia de fundaciones}

El art. 28 de la Ley 50/2002, de 26 de diciembre, de Fundaciones (en adelante LF), establece que:

«Los patronos podrán contratar con la fundación, ya sea en nombre propio o de un tercero, previa autorización del Protectorado, que se extenderá al supuesto de personas físicas que actúen como representantes de los patronos».

El art. 34 del Real Decreto 1337/2005, de 11 de noviembre, por el que se aprueba el Reglamento de Fundaciones de Competencia Estatal (en adelante RF), dispone que:

«1. La solicitud de autorización para que los patronos sean remunerados o contraten con la fundación, por sí o por medio de representante, a que se refieren los arts. 15.4 y 28 de la Ley 50/2002, de 26 de diciembre, de Fundaciones, será cursada al Protectorado por el patronato y habrá de ir acompañada de la siguiente documentación: 
a) Copia del documento en que se pretende formalizar el negocio jurídico entre el patrono y la fundación.

b) Certificación del acuerdo del patronato por el que se decide la realización del negocio jurídico, incluyendo el coste máximo total que supondrá para la fundación.

c) Memoria explicativa de las circunstancias concurrentes, entre las que se incluirán las ventajas que supone para la fundación efectuar el negocio jurídico con un patrono.

2. El Protectorado resolverá y notificará la resolución en el plazo de tres meses, entendiéndose estimada la solicitud si, transcurrido dicho plazo, no hubiese recaído resolución expresa ni hubiese sido notificada.

3. El Protectorado denegará en todo caso la autorización en los siguientes supuestos:

a) Cuando el negocio jurídico encubra una remuneración por el ejercicio del cargo de patrono.

b) Cuando el valor de la contraprestación que deba recibir la fundación no resulte equilibrado.

4. También deberá el patronato solicitar autorización del Protectorado, en los términos establecidos en los apartados anteriores, para designar como patrono a una persona, natural o jurídica, que mantenga un contrato en vigor con la fundación».

Lo que se deduce de lo anterior es que la LF y el RF exigen la previa autorización del Protectorado en los casos de autocontratación y que la misma se entiende que concurre cuando los patronos pretenden contratar con la fundación, ya sea en nombre propio o de un tercero. La exigencia de previa autorización del Protectorado se extiende por la ley al supuesto de personas físicas que actúen como representantes de los patronos.

Estas previsiones no son las que se contemplan en el ámbito del Derecho civil (salvo en la Ley de Fundaciones), en que se entiende que se produce la autocontratación en los supuestos que se indican a continuación y en que dicha figura se admite cuando no se produce conflicto de intereses.

En efecto, la Dirección General de los Registros y del Notariado declara, en Resolución de 11 de diciembre de 1997 (Ar. 8822), que la autocontratación se funda en el supuesto de incompatibilidad de intereses, es decir, que se produce la autocontratación cuando una misma persona tiene facultades, emanadas de la ley o de la voluntad contractual normalmente vía poder, para vincular los patrimonios de dos personas, ocasionando un conflicto de intereses y, por consiguiente, perjuicio para uno de los patri- 
monios afectados, de forma que no queda garantizada la independencia necesaria entre los procesos de formación de las voluntades emitidas.

La Sentencia del Tribunal Supremo de 20 de noviembre de 2002 (Ar. 7322) declara, en ese sentido, que «el autocontrato o negocio jurídico del representante consigo mismo es válido, en principio; no lo es cuando en casos concretos la ley lo prohíbe, porque advierte que puede haber conflicto de intereses, y cuando, aunque la ley nada disponga, se produce tal conflicto; en todo caso, es válido cuando se ha autorizado expresamente en el poder de representación. La Sentencia de esta Sala de 12 de junio de 2001 (RJ 2001, 5058) recoge (en su fundamento 2. ${ }^{\circ}$, párrafo 3..$^{\circ}$ ) la doctrina jurisprudencial, que ahora se asume y ratifica, destacando que es válido el autocontrato en el que hay una "previa licencia", lo que se reitera de nuevo. Dice así, literalmente, dicha sentencia: "Hipótesis de autocontrato, o contrato consigo mismo, es la modalidad más genuina (y tachada de más peligrosa por el mayor riesgo de parcialidad) que se da cuando existe una sola voluntad que hace dos manifestaciones jurídicas conjugadas y económicamente contrapuestas [Resolución de 9 de febrero de 1946 (RJ 1946, 549)], es decir, cuando una persona cierra consigo misma un contrato actuando a la vez como interesada y como representante de otra [Sentencia de 5 de noviembre de 1956 (RJ 1956, 3430)]. La figura jurídica carece de una regulación general en nuestro Derecho positivo, aunque se refieren a la misma diversos preceptos aislados (singularmente destacan los arts. 1.459 CC y 267 CC) y ha sido objeto de una importante atención, tanto por el órgano directivo registral [entre otras, RR de 29 de diciembre de 1922, 30 de mayo de 1930 (RJ 1930, 31), 3 de noviembre de 1932 (RJ 1932, 1263), 23 de enero (RJ 1943, 117) y 9 de marzo de 1943 (RJ 1943, 342), 4 de mayo de 1944 (RJ 1944, 687), 9 de febrero de 1946 (RJ 1946, 549), 26 de septiembre de 1951 (RJ 1951, 2037), 9 de mayo de 1978 (RJ 1978, 2493), 1 de febrero de 1980 (RJ 1980, 506), 29 de abril de 1993 (RJ 1993, 3010), 11 de diciembre de 1997 (RJ 1997, 8822), 11 (RJ 1998, 4121) y 14 de mayo (RJ 1998, 4455) y 2 de diciembre de 1998 (RJ 1998, 10481)], como por la jurisprudencia de esta Sala [SS de 7 de noviembre de 1947 (RJ 1947, 1218), 5 de noviembre de 1956 (RJ 1956, 3430), 22 de febrero de 1958 (RJ 1958, 1420), 11 de junio (RJ 1966, 3406), 14 y 27 de octubre de 1966 (RJ 1966, 4767), 30 de septiembre de 1968 (RJ 1968, 5164), 5 de febrero de 1969 (RJ 1969, 586), 23 de mayo de 1977 (RJ 1977, 2135), 3 de noviembre de 1982 (RJ 1982, 6523), 8 de noviembre de 1989 (RJ 1989, 7861), 31 de enero (RJ 1991, 521) y 29 de octubre de 1991 (RJ 1991, 7243), 24 de septiembre de 1994 (RJ 1994, 6988), 26 de 
febrero (RJ 1996, 1606) y 15 de marzo de 1996 (RJ 1996, 2367), 9 de junio de 1997 (RJ 1997, 4733), 20 de marzo de 1998 (RJ 1998, 1712), 12 de febrero de 1999 (RJ 1999, 654), 28 de marzo de 2000 (RJ 2000, 1783) y 19 de febrero de 2001 (RJ 2001, 2584)], quedando supeditada su validez, en sintonía con la finalidad de prevenir la colisión de intereses, a la existencia de un conflicto de éstos y la falta de la previa licencia o posterior asentimiento o ratificación del interesado, sin que la previa autorización para contratar, aunque haya de constar con claridad, esté sujeta a requisitos especiales, por lo que, salvo que otra cosa se disponga, no hay más exigencias que las del propio poder que modaliza. Este criterio de flexibilidad formal es el que prevalece en la doctrina científica, en las decisiones de la DGR y en la jurisprudencia de esta Sala. Así, Resoluciones de 23 de enero de 1943 (cuando el poderdante conceda al apoderado las facultades necesarias con la vista puesta en el posible conflicto de intereses o cuando no pueda surgir éste al determinar el contenido del contrato); 4 de mayo de 1944 (exigir con todo rigor que conste la clara expresión de que se faculta al representante para que actúe con el doble carácter); 26 de septiembre de 1951 y 11 de diciembre de 1997 (facultades explícitas para celebrarlo, pues no basta la atribución genérica de poderes o facultades); 1 de febrero de 1980 y 11 de mayo de 1998 (cuando esté expresamente autorizado para ello o esté autorizado para el acto específico donde existe la contraposición); 14 de mayo de 1998 (cuando el potencial perjudicado haya convenido o autorizado a su representante para contratar o actuar como representante múltiple), y 2 de diciembre de 1998 (la doctrina jurisprudencial es favorable a la validez de la figura si media la pertinente licencia del principal), y Sentencias, entre otras, de 5 de noviembre de 1956, 22 de febrero de 1958, 14 y 27 de octubre de 1966 y 23 de mayo de 1977 (poder expreso o que de los términos en los que aparezca extendido el poder con el que el representante actúa permitan calificarle de adecuado, suficiente o bastante para poder celebrar contratos consigo mismo), siendo de destacar la Sentencia de 15 de marzo de 1996 que no sólo confirma la anterior doctrina general, sino que incluso se refiere a un caso en que se recogía una cláusula ("ejercitar las facultades anteriormente referidas, aunque incida en autocontratación') sensiblemente similar al supuesto de autos"».

Sin embargo, en el ámbito de la Ley de Fundaciones resulta que están sujetos a previa autorización del Protectorado los contratos que pretendan suscribir los patronos en su propio nombre o de un tercero con la fundación, y el Protectorado tendrá que apreciar si existe o no conflicto de intereses y denegar la autorización en los casos previstos en el Reglamento. 
En un supuesto concreto que se planteó en su momento a la Abogacía del Estado resultó que una fundación (en su representación, el presidente de la fundación) y una universidad (en su representación, el rector de la universidad) suscribieron un documento por el que se regulaba la construcción, financiación, destino y uso de un nuevo edificio complementario en los terrenos que la fundación tenía en una determinada localidad en el que se convino el arrendamiento del inmueble por un plazo inicial de diez años por un determinado precio, y que la universidad se financiaría, para hacer frente a los pagos de la construcción del inmueble, a través de una póliza de crédito sujeta a las condiciones que recogía el documento (por una determinada cantidad). En su momento, la fundación y la universidad (en su representación, el presidente de la fundación y el rector de la universidad) formalizaron las condiciones en que la universidad anticipó el importe de las certificaciones de obra hasta una determinada cantidad.

En virtud de contrato de arrendamiento suscrito entre las partes, la universidad se comprometió a satisfacer por adelantado una determinada cantidad, contrato que se firmó por el presidente de la fundación y el rector de la universidad.

La fundación había reconocido que eran patronos natos de la fundación el rector de la universidad y el vicecanciller de la misma.

Por tanto, resulta claro que en este supuesto los patronos de la fundación han contratado con la fundación en nombre de un tercero y que era necesaria la previa autorización.

Es cierto que la universidad no era patrono de la fundación y que, en ese sentido, no había contratado la universidad en nombre propio. También lo es, como invocó la fundación, que la universidad no era fundadora de la fundación. Pero, en cualquier caso, eran patronos natos de la fundación los cargos que se han indicado de la universidad en su condición precisamente de tales cargos de la universidad, no en cuanto personas físicas con sus nombres y apellidos, por lo que resulta evidente que los patronos en cuestión habían contratado con la fundación en nombre del tercero que es la universidad.

El informe 37/09 redactado el 17 de septiembre de 2009 por Óscar Sáenz de Santa María Gómez-Mampaso (publicado en los Anales de la Abogacia General del Estado de 2009) precisamente permite concluir lo mismo y no permite amparar la solicitud de la fundación.

En efecto, el indicado informe, después de reconocer que el CSIC no es patrono de la FGCSIC, añade que: «La problemática pasa ahora al examen de si los patronos natos, actuando en representación de un tercero, 
el CSIC, se someten a la necesidad de autorización referida [...] En la persona del presidente del CSIC concurre la cualidad de patrono (presidente del patronato) y de la persona que actúa en representación del propio CSIC a todos los efectos y, en particular, y aun cuando delegue su competencia, cuando se trate de suscribir contratos, convenios o negocios jurídicos en nombre del CSIC. El supuesto incurre de plano, en consecuencia, en lo dispuesto en el art. 28 mentado cuando se refiere a la contratación que realiza un patrono (el presidente del patronato de la FGCSIC) a nombre de un tercero (el CSIC, por el cual actúa en su calidad de presidente de dicha agencia). No obstante lo anterior, lo expuesto no implica que no puedan celebrarse este tipo de contratos o convenios ni, por supuesto, que su concierto no pueda ni deba ser autorizado por el Protectorado, y más atendiendo a la finalidad con la que la fundación fue creada, a la legislación y doctrina aplicables antes expuesta, y, lo que es más importante, a la propia finalidad por la que se rigen las normas que regulan la autocontratación [...] Puede entonces precisarse que, como se ha dicho, la ley exige autorización del Protectorado cuando un patrono contrate con la fundación, y que, en el caso de que este contrato se refiera directamente al patrono, deberá cursarse la solicitud en los términos del art. 34 del Real Decreto, mas en el supuesto en que no se refiera directamente al patrono, sino cuando éste actúa en representación de un tercero, si bien se precisa autorización del Protectorado, la misma no se rige por las mismas prescripciones o, al menos, sólo cabría acudir a ellas por analogía (art. 4.1 CC)».

Se entiende, por tanto, que en este supuesto ha existido autocontratación y la misma debió ir precedida de la correspondiente y necesaria autorización del Protectorado.

Los contratos concertados por los patronos de la fundación eran contratos privados que se hallaban sujetos a las normas de Derecho privado y resulta que se habían realizado sin la previa autorización cuando ésta era necesaria.

Por tanto, se puede acudir a la doctrina general sobre la nulidad y la anulabilidad de los negocios jurídicos expuesta anteriormente para determinar las consecuencias de la falta de la necesaria y previa autorización.

De acuerdo con lo indicado al respecto, en los contratos concertados por los patronos de la fundación no concurría ninguna causa de anulabilidad de los contratos conforme a lo regulado por el Código Civil, sino que se trataba de lo que Federico de Castro y Bravo ${ }^{14}$ había denominado nego-

${ }^{14}$ F. de Castro y Bravo, El negocio jurídico, op. cit., pp. 485 y 486. 
cios incompletos, porque faltaba la necesaria y previa autorización para que fueran negocios jurídicos completos; falta a la que se anuda la sanción de nulidad por ser contrario el negocio jurídico a la norma imperativa.

En el mismo sentido se pronuncia Rafael Ballarín Hernández ${ }^{15}$ al afirmar que el art. 1.259 CC permite calificar el acto de incompleto, por su estructura, y, por su eventual eficacia, de sanable. El art. 1.259 CC considera que el contrato celebrado a nombre de otro por quien no tenga su autorización o representación legal será nulo, a no ser que lo ratifique la persona en cuyo nombre se otorgue antes de ser revocado por la otra parte contratante.

Marta Pérez Escolar, Miguel Ángel Cabra de Luna y Rafael de Lorenzo García ${ }^{16}$ entienden que cabe «que se tenga en cuenta que se trata más bien de un "negocio incompleto o inacabado en una species facti negocial compleja de formación sucesiva" todavía abierta y a la espera de recibir el elemento del supuesto de hecho que lo completara [...]; desde este punto de vista y en base al art. 1.259 del Código Civil puede entenderse que "los negocios realizados por el patronato sin haber obtenido la previa autorización del Protectorado son ineficaces en tanto no vinculan a la fundación [...] No obstante, el Protectorado podrá con posterioridad otorgar la autorización necesaria"».

En este supuesto, en que se está ante negocios jurídicos incompletos, $\mathrm{y}$, por tanto, nulos por ser contrarios a la norma imperativa, y en que no concurrían las causas de anulabilidad contempladas en el Código Civil, se entiende que es posible aplicar la opinión doctrinal de Federico de Castro y Bravo sobre la posibilidad de convalidación de los negocios incompletos en casos como éste, en que el negocio requería para su validez una autorización posterior o una aprobación formal (administrativa en este caso) que viniera a «subsanar la nulidad».

$\mathrm{El}$ art. $21 \mathrm{RF}$ recoge expresamente esta posibilidad al disponer que:

«1. Cuando el Protectorado tenga conocimiento de que se han realizado actos de disposición o gravamen sin la preceptiva autorización o sin cumplir la obligación de comunicar el acto o negocio realizado, requerirá al patronato cuanta información considere conveniente. El patronato dispondrá de un plazo de quince días para suministrar dicha información.

15 R. Ballarín Hernández, Comentarios a la Ley de Fundaciones, coordinado por J. Olavarría Iglesia, Valencia, Tirant lo Blanch, 2008, pp. 768 y ss.

${ }_{16}$ M. Pérez Escolar, M. Á. Cabra de Luna y R. DE Lorenzo García, «Patrimonio, régimen económico y funcionamiento», en R. De Lorenzo, J. L. Piñar y T. Sanjurjo (dirs.), Tratado de Fundaciones, cap. V, Cizur Menor, Aranzadi-Thomson Reuters, 2010, p. 322. 
2. El Protectorado, a la vista de las circunstancias concurrentes, resolverá sobre la procedencia de subsanar el defecto y autorizará a posteriori el negocio efectuado, sin perjuicio de la posibilidad de entablar la acción de responsabilidad contra los patronos o de solicitar de la autoridad judicial su destitución».

C. Falta de autorización previa del Protectorado en caso de enajenación o gravamen de los bienes y derechos que forman parte de la dotación o están directamente vinculados al cumplimiento de los fines fundacionales en materia de fundaciones

El art. 21.1 LF establece que:

«1. La enajenación, onerosa o gratuita, así como el gravamen de los bienes y derechos que formen parte de la dotación o estén directamente vinculados al cumplimiento de los fines fundacionales, requerirán la previa autorización del Protectorado, que se concederá si existe justa causa debidamente acreditada.

2. Se entiende que los bienes y derechos de la fundación están directamente vinculados al cumplimiento de los fines fundacionales cuando dicha vinculación esté contenida en una declaración de voluntad expresa, ya sea del fundador, del Patronato de la fundación o de la persona física o jurídica, pública o privada, que realice una aportación voluntaria a la fundación, y siempre respecto de los bienes y derechos aportados.

Asimismo, la vinculación a que se refiere el párrafo anterior podrá realizarse por resolución motivada del Protectorado o de la autoridad judicial».

La Sentencia del Tribunal Supremo de 7 de marzo de 2011 (RJ 2011/2757) señala lo siguiente en su segundo Fundamento de Derecho:

«El motivo se desestima porque de aceptarse la tesis del recurso no tendría sentido el precepto que distingue entre los bienes directamente vinculados, para cuya enajenación o gravamen es precisa la autorización del Protectorado, de aquellos otros que únicamente exigen la comunicación a éste. Las normas que se indican en el motivo se refieren a una vinculación genérica, pero para que sea operativa la exigencia de la autorización es precisa una vinculación expresa y concreta. En tal sentido se manifiesta el art. 21.2 de la Ley de Fundaciones, que contiene una norma de interpretación auténtica que dice "se entiende que los bienes y derechos de la fundación están directamente vinculados al cumplimiento de los fines fundacionales cuando dicha vinculación esté contenida en una declaración de 
voluntad expresa, ya sea del fundador, del patronato de la fundación o de la persona física o jurídica, pública o privada, que realice una aportación voluntaria a la fundación, y siempre respecto de los bienes y derechos aportados", añadiendo en el párrafo siguiente que "asimismo, la vinculación a que se refiere el párrafo anterior podrá realizarse por resolución motivada del Protectorado o de la autoridad judicial", y en tal sentido se manifestó la resolución recurrida, en la que se declara que "no existe resolución motivada del Protectorado, ni de la autoridad judicial, ni mucho menos del fundador, ni de la sociedad que donó dicho edificio" de voluntad expresa de vinculación; lo que ni siquiera se ha intentado desvirtuar».

El art. 17.1 RF prevé en el mismo sentido que:

«1. Están sometidos a un régimen de autorización previa del Protectorado los actos de enajenación, onerosa o gratuita, o de gravamen de los bienes y derechos que formen parte de la dotación y de los directamente vinculados al cumplimiento de los fines fundacionales, que se concederá si existe justa causa debidamente acreditada».

La solicitud de autorización deberá acompañarse de los siguientes documentos que recoge el art. $18 \mathrm{RF}$ :

a) Certificación del acuerdo adoptado por el patronato de la fundación.

b) Memoria acreditativa de las características del bien o derecho objeto del acuerdo y de los elementos y condiciones del negocio jurídico, con exposición de las razones en que se fundamenta e indicación del destino del importe.

c) Valoración de los bienes y derechos realizada por un experto independiente. Tratándose de valores cotizados en un mercado secundario oficial, tendrá la consideración de informe de experto independiente la certificación de una entidad gestora que opere en dicho mercado en la que se acredite la valoración de los títulos de acuerdo con la cotización media del último trimestre.

La solicitud de autorización deberá contener expresión de las circunstancias siguientes, según el mismo art. 18 RF:

a) Cuando se trate de préstamos hipotecarios, se ha de determinar expresamente la cuantía y el destino del principal, la valoración del bien de conformidad con los criterios utilizados habitualmente por las entidades de crédito, los intereses pactados y el plazo para el cumplimiento de la obligación garantizada. 
b) Cuando se trate de usufructos, derechos de superficie u otra clase de gravámenes, se ha de expresar el valor de los derechos reales que se pretende constituir, su duración y los elementos y condiciones esenciales del gravamen. A los efectos de valoración del derecho real que se pretenda constituir se estará a lo prevenido en las normas reguladoras del Impuesto sobre Transmisiones Patrimoniales relativas a la constitución de derechos reales.

El art. $19 \mathrm{RF}$ regula el procedimiento que se ha de seguir para obtener la autorización administrativa. Teresa Martín García de Leonardo ${ }^{17}$ entiende que «las resoluciones correspondientes no tienen que consistir necesariamente en conceder o denegar la autorización, sino que podrán condicionarse a que se tomen algunas precauciones para disminuir los riesgos con respecto al patrimonio fundacional. La finalidad de la autorización es hacer efectivo el cumplimiento de los fines establecidos para la voluntad fundacional». El art. $20 \mathrm{RF}$ regula la autorización anual para la enajenación de valores cotizados y el art. 21 regula los efectos de la falta de autorización.

La misma autora ${ }^{18}$ considera que «la exigencia de autorización previa se refiere tanto a los bienes inmuebles como a los muebles que formen parte de la dotación. No se comprende cómo el legislador no ha tenido en cuenta los supuestos que podemos denominar excepcionales — venta de bienes inmuebles o de valores que coticen en Bolsa- y continúa exigiendo la autorización previa. Por otra parte, al amparo de la legislación anterior se suscitó la duda de si el dinero que formase parte de la dotación estaba sujeto o no a autorización previa en los supuestos de enajenación o gravamen, ya que el texto del art. 19 establecía que la autorización "no será necesaria en el caso de los actos de disposición de donaciones o subvenciones conforme a los fines establecidos por el donante o la correspondiente norma". La doctrina se pronunció por la exigencia de autorización, ya que "si consideramos un negocio jurídico en el que el dinero resulta gravado, por ejemplo, por aval de un tercero, de estimar que no requeriría autorización del Protectorado nos encontraríamos con que los patronos pueden poner en grave riesgo el patrimonio de la fundación, con la posibilidad de que la fundación no perciba una contrapartida equivalente. El término gravamen deja poco lugar a dudas sobre el espíritu de

17 T. Martín García de LeOnardo, Comentarios a la Ley de Fundaciones, coordinado por J. OlavarRía Iglesia, Valencia, Tirant lo Blanch, 2008, pp. 561 y ss.

${ }_{18}$ Ibid., pp. 564 y 565. 
la Ley" ${ }^{19}$. De ahí que en la actualidad se puede considerar que está sometido a la exigencia de autorización previa si forma parte de la dotación o está directamente vinculado al cumplimiento de los fines fundacionales».

Es cierto que la misma autora considera ${ }^{20}$ que el negocio jurídico celebrado sin autorización cuando no hay posibilidad de subsanación será un negocio que deviene ineficaz al modo del art. 1.259 CC.

Otros autores ${ }^{21}$ consideran que «el acto de disposición realizado por la fundación sin haberse solicitado la autorización del Protectorado siendo ésta preceptiva es un acto contrario a la ley, en concreto al art. 2.1. LF, cuyo régimen de invalidez no se ajusta a las categorías clásicas de la nulidad de pleno derecho y de la anulabilidad. Ante ello, pensamos que la opción más correcta es la de calificarlo como negocio jurídico incompleto, que queda afectado de una invalidez provisional cuya resolución definitiva se hace depender de la ratificación posterior del Protectorado: si se llega a esta ratificación el negocio se convierte en válido con carácter definitivo y con efectos retroactivos al momento de su celebración; en caso contrario, el acto de disposición debe considerarse ineficaz igualmente con efectos retroactivos».

En cualquier caso, se considera que el negocio jurídico incompleto es un contrato que por contravenir una norma imperativa, sin que concurra causa de anulabilidad, sería más bien un contrato nulo, sin perjuicio de la posibilidad de su convalidación por la autorización posterior del Protectorado de acuerdo con lo dispuesto en el art. $21 \mathrm{RF}$.

\section{CONCLUSIONES}

La doctrina ${ }^{22}$ y la jurisprudencia del Tribunal Supremo ${ }^{23}$ coinciden en considerar como negocios jurídicos incompletos aquellos negocios jurí-

19 J. García Andrade, La Fundación: un estudio jurídico, Madrid, Fundación OnceEscuela Libre Editorial, 1997, p. 152, y C. VATTIER FuENZALIDA, «El régimen del patrimonio fundacional», Revista Jurídica La Ley, núm. 5 (2001), p. 4.

${ }^{20}$ T. Martín García de LeOnardo, Comentarios a la Ley de Fundaciones, op. cit., p. 587.

${ }^{21}$ M. Pérez Escolar, M. Á. Cabra de Luna y R. de Lorenzo García, «Patrimonio, régimen económico y funcionamiento», op. cit., pp. 271 y 272.

22 F. de Castro y Bravo, El negocio jurídico, op. cit., p. 447; R. Ballarín Hernández, Comentarios a la Ley de Fundaciones, op. cit., pp. 768 y ss., y M. Pérez Escolar, M. Á. CABRA DE Luna y R. DE LoRenzo García, «Patrimonio, régimen económico y funcionamiento», op. cit., p. 322.

${ }^{23}$ SSTS de 28 de octubre de 2014 (RJ 2014/5847) y de 23 de septiembre de 2010 (JUR 2010/558), y STSJ de Madrid de 15 de septiembre de 2015 (JUR 2015/241841). 
dicos que se realizan sin la previa autorización judicial o administrativa. También coinciden en entender que tales negocios jurídicos incompletos son susceptibles de convalidación por la posterior autorización judicial o administrativa, incluso así lo contempla el RF en determinados supuestos en que falta la previa autorización del Protectorado cuando se han realizado actos de disposición o gravamen sin la misma.

En lo que disienten unos y otros es en las consecuencias de los negocios jurídicos incompletos, esto es, si son actos nulos o anulables. Por una parte, algunos autores consideran que se trata de actos nulos por ser contrarios a normas imperativas ${ }^{24}$ o por aplicación del art. $1.259 \mathrm{CC}^{25}$. Por otra parte, otros autores y algunas sentencias del Tribunal Supremo ${ }^{26}$ entienden que se trata de actos anulables por aplicación de otros preceptos que se aprecia que contemplan esta ineficacia relativa.

Nos inclinamos, como indicamos a lo largo de este artículo, por la postura doctrinal de Federico de Castro, que parte del presupuesto de que se trata de actos nulos, se entiende que por ser contrarios a las normas imperativas que incumplen y que establecen la previa autorización judicial o administrativa, razón por la que se ha expuesto la doctrina general sobre el particular con inclusión de la aplicación de determinados supuestos de nulidad en determinados ámbitos, aunque lo realmente importante, en definitiva, es que tanto la doctrina como la jurisprudencia del Tribunal Supremo admiten la convalidación civil en estos supuestos.

${ }^{24}$ F. DE CASTRo, El negocio jurídico, op. cit., p. 447.

25 R. Ballarín Hernández, Comentarios a la Ley de Fundaciones, op. cit., pp. 768 y ss.; M. Pérez Escolar, M. Á. Cabra de Luna y R. de Lorenzo García, «Patrimonio, régimen económico y funcionamiento», op. cit., p. 322, y T. MARTín GARCÍA DE LEONARDO, Comentarios a la Ley de Fundaciones, op. cit., p. 587.

26 STS de 23 de septiembre de 2010 (JUR 2010/558). 